\title{
The Spirit of God in the New Testament: Diverse witnesses
}

\author{
Andries van Aarde \\ Department of New Testament Studies (Sec A) \\ University of Pretaria
}

\begin{abstract}
The article begins with a discussion of the development of the doctrine with regard to the Holy Spirit. This development took place in three phases: from apocalypticism to the Nicene Creed to the Reformation. In the doctrine of the Triune God the Holy Spirit functions as the third persona. In the New Testament the Spirit of God should be seen against the background of intermediary and apocalyptic figures. A comparison of passages in Luke-Acts, the Gospel of John and Paul's letter to the Romans attests to a diversity of witnesses with regard to the Spirit of God. The article includes a discourse on the nature of the charismatic gifts of the Holy Spirit witnessed in 1 Corinthians 12. By way of conclusion, a list of recommended publications with regard to the Biblical witness of the Spirit of God is presented.
\end{abstract}

\section{FROM APOCALYPTICISM TO THE NICENE CREED TO THE REFORMA- TION}

1.1 The Spirit of God seen against the background of intermediary and apocalyptic figures

Speaking about God cannot but be influenced by our present frame of reference and mind set. The same is true with regard to the Holy Spirit as the third persona in the Christian's understanding of God as Triune. Christians' understanding of the Holy Spirit is conditioned by their understanding of the interrelationship of the work of the Father, Son and the Spirit. However, in Biblical interpretation, one should be cognizant of the hermeneutical fallacy of anachronism. Connotations attached to words or

* This research is conducted for the use of advanced theological instruction for ministers of both the Hervormde Kerk in Suidelike Afrika (1997) and the Nederduitsch Hervormde Kerk (1999). 
phrases because of the later development of theological or philosophical conceptual constructs in institutionalized Christendom should not constitute the frame of reference for Bible interpretation. The meaning and reference of words and concepts in the Bible and its contemporary related literature and artifacts should be interpreted in their own terms. This hermeneutical principle is extremely important if we are interested to know what a native audience would consider these words or concepts to mean.

For example, the use of the concept 'Holy Spirit' in Matthew 1:18 and 1:20, 23 (or 'God's Spirit' in 12:28) and 28:19 cannot simply be interpreted as referring to the third person of the Trinitarian formula. Matthew 28:19 reads: 'All authority in heaven and on earth has been given to me. Therefore, make disciples of all nations, baptize them in the name of the Father and of the Son and of the Hoty Spirit and teach them to obey every thing I have commanded you. And surely I am with you always, to the very end of the age' (NIV; with my adaptation). This threefold formula is an (apocalyptic) allusion (with verbal correspondences) to the tri-partition of Daniel 7:13-14:

In my vision at night I looked, and there before me was one like a son of man, coming with the clouds of heaven. He approached the Ancient of Days and was led into the presence [of those who encircled God's throne, angelic figures]. He was given authority, glory and sovereign power: all peoples, nations and men of every language worshipped him. His dominion is an everlasting dominion that will not pass away, and his kingdom is one that will never be destroyed.

(New International Version)

In this report of victory over death, vindication (despite suffering) and 'authority' over the nations (despite the might of worldly powers), the author of the book Daniel refers to the vindicated 'Son of Man'. The Son of Man is mentioned in relation to the 'Ancient of Days' and the 'angels'. Matthew 28:19 is a report of Jesus' victory over death. It is also a report of vindication despite suffering and authority over the nations despite the might of worldly powers. Matthew's tri-partition of Father, Son and Spirit is used in analogy of the tri-partition in Daniel of 'Ancient of Days', 'Son of Man' and 'angels. The expression 'I am with you' (Mt 28:20) harks back to the birth of Jesus, which Matthew describes as 'God with us'. This phraseology alludes to the Greek (Septuagint) translation of Isaiah 7:14 and Isaiah 8:8. It expresses God's presence among God's people. 
In numerous examples of the same threefold formula (though not always in the same sequence) in the New Testament (as well as in the so-called intertestamentary literature or Old Testament pseudepigraphs) the term 'Holy Spirit(s)' is used within an apocalyptic frame of reference and sometimes in the same vein as the 'holy angels' (see, e g, Mk 8:38; Mk 13:32; Mt 25:31-43; Mt 13:36-43; Lk 12:8-9; 1 Th 4:13-18; 2 Th 1:5-10; Rev 1:4- 7; 5:6-7; 11:15-18).

When the concept 'Spirit of God' is seen against the background of intermediary and apocalyptic figures a rather confusing picture appears. What then is the difference between the 'angel' and the 'Spirit of God'? A closer look at the pseudepigraph Martyrdom and Ascension of Isaiah, written between the 2nd century BCE and the 4th century CE illustrates a shift in function between the notion 'holy spirit' as one among other divine intermediary figures, and the 'Holy Spirit' as an 'angel' distinctive from other 'angels'. This composite writing (consisting of an early Semitic-Hellenistic fragment with later Christian interpolations and a Christian fragment) reveals the development of an ontological conceptualization of God as God-Triune. The Semitic fragment describes Isaiah's martyrdom by Manasseh while a Christian interpolation presents a vision of Isaiah before Manasseh arrested him. This vision reveals the life and death of 'the Beloved' (Jesus as 'Lord'), the corruption of the church, the reign of 'Beliar' ('Satan', also referred to as 'Sammael', 'Malkira' or 'Matanbukus') and the Second Coming of the 'Lord'. The corruption is about, among others, 'wicked elders' who seek office for the sake of money and it could refer to Constantine's policy to pay bishops salaries.

The expression 'angels' appears in the earlier Semitic-Hellenistic fragment indicating Satan's messengers and Beliar as the 'angel of iniquity' (MartIs 1:3-4). In the interpolated Christian vision a distinction is made between Michael the 'chief of the holy angels' (MartIs 3:16) and Beliar or 'Sammael ... exposed from the heavens' (MartIs 3:13). In this vision there is also a reference to the descent of an 'angel of the church which is in the heavens'. This angelic figure seems to be the symbolic 'heavenly' counterpart of the 'twelve disciples' who were sent out to teach all nations (MartIs 3:15, 18). In Revelation 1:20 we find a similar image. Here the 'seven stars' are the 'angels of the seven churches'. The 'universal' number seven expands the 'particularistic' number twelve. The seven churches are symbolized by the 'seven lampstands'. Someone 'like the Son of Man' (Rev 1:13) appeared among the seven lampstands. The seven churches are the transcendental counterpart of the evangelized church, including Israelites and believers from the gentile world.

In the Christian addition to the Martyrdom and Ascension of Isaiah (chapters 6-11) the author defended the concept of the Trinity in terms of incarnation. This defense de- 
scribes a vision the author experienced in the 'seventh heaven' in which he saw 'angels' who are 'the righteous' (among them Adam, Abel and Seth are mentioned) (cf MartIs 9:28). The author, himself transformed into an angel, was led by a leader among the angels to worship 'the Lord' (MartIs 9:32). A 'second angel' appeared to 'left of the Lord'. The author asked the leader: 'Who is this one?' The leader among the angels responded: 'Worship him, for this is the angel of the Holy Spirit who has spoken in you and also in the other righteous' (MartIs 9:36).

There are scholars who have interpreted the expression 'the angel of the Holy Spirit' as a reference to Gabriel. However, it should rather be seen grammatically as a hendiadys. A hendiadys is a grammatical style in Greek where one concept is expressed by means of two lexical units. An example of this can be found in 1 Thessalonians 1:5 where 'power' and 'Holy Spirit' refer to the one concept, namely the Spirit of God. So also the 'angel of the Holy Spirit' are two units expressing one concept, namely the Spirit of God. Here we have a clear indication of the first step in the development of the doctrine of the Triune God. During this incipient phase of the development a superior status is attributed to the Father in that 'the Lord' and the 'angel of the Holy Spirit' are presented as worshipping 'the Father' (cf MartIs 9:40).

Although the above-mentioned apocalyptic passages in the New Testament witness to a triadic idea, the ontological dogma of the Triune God is not presented. Yet it seems confusing that angels and the Holy Spirit are mentioned in the same breath. However, it is in fact simply a reference to God's presence among God's people. Psalm 139:7ff reads:

Where can I go from your Spirit?

Where can I flee from your presence?

If I go up to the heaven, you are there;

if I make my bed in the depths, you are there.

If $I$ rise on the wings of the dawn,

if I settle on the far side of the sea, even there your hand will guide me, your right hand will hold me fast.

In these words the 'Spirit' is the leading concept for the portrayal of the divine presence on earth. Here God's presence is not described in terms of the concepts and symbols of the Jerusalem cult. Traditionally, the seven-branched lampstand (menorah) in the Temple (Ex 25:31-37; Zech 4:2) symbolized God's presence on earth. In a vi- 
sion the author of Revelation (1:12-20) experienced God's presence by seeing someone 'like the son of man' among the lampstands. The 'son of man' held in his right hand seven stars. This is a metaphor for God's omnipresence. In the vision the 'Son of Man' explained the metaphor to John: 'The mystery of the seven stars that you saw in my right hand and of the seven golden lampstands is this: "The seven stars are the angels of the seven churches, and the seven lampstands are the seven churches"' (Rev 1:20). The 'Son of Man' said about himself: 'I am the living One: I was dead, and behold I am alive forever and ever' (Rev 1:18). Here we have a reference to both the Spirit-filled church and the Spirit-filled Son of Man, indicating God's presence among God's people. The Son of Man 'who holds the seven stars in his right hand ... walks among the seven golden lampstands' (Rev 2:1). In Revelation 2:7 ['listen to what the Spirit is saying to the churches!'] the speaker, who is the Son of Man, and the Spirit are equivalent.

However, the author of Hebrews (1:5-14), combining Psalm 2 with Psalm 110, says that at the incarnation of the 'Son of the Father' God transformed God's 'angels' (angeloi) into 'spirits' (pneumata). These 'spirits' are 'flames of fire' and they worshipped God's 'Firstborn' (prototokos). In other words, according to Hebrews, the angels are subordinated to God's Son. Here the emphasis is laid on the incarnation.

The report of the first vision in Revelation (1:9-20) represents a later version of the so-called kerygmatic tradition. In the kerygmatic tradition the presence of God manifests in the vindication of Jesus as Messiah and Son of Man. This tradition stemmed from the earliest Jesus movement in Jerusalem and was also transmitted by Paul and the synoptic gospels. It is about the 'good news' (euangelion) that God's kingdom has been inaugurated as a spiritual reality in the lives of believers through Jesus' crucifixion and resurrection. What is remarkable about the kerygmatic tradition is that the crucified and resurrected Jesus as the Messiah or as the Son of Man manifests God's presence (see Mt 28:19f). In the Pauline version of the kerygmatic tradition Jesus is the exalted Lord (Kurios) who was manifested (declared as) Son of God at his victory over death (resurrection) (see Rm 1:3-4). Mark resembles both the tradition with regard to Jesus as the Son of Man (see Mk 8:31; 9:31; 10:33) and Jesus as Son of God (see Mk 15:39).

The presence of God was often articulated by means of 'substitutes'. In the Old Testament there are numerous examples where 'substitutes' for God are mentioned, for example 'messengers', 'glory', 'wisdom' and 'Spirit'. We have seen that 'Spirit' and 'messengers' ('angels') were related. A recent study (see list of recommended publications) also shows that the idea of 'wisdom' in the Letter of James is more or less interchangeable with the concept of the 'Holy Spirit' in other New Testament books 
(especially in the epistles of Paul). This research is based on a study of parallel ideas in the New Testament, the Wisdom Literature and the Qumran texts. It argues that the identification of 'wisdom' (in James) with 'Holy Spirit' (in Paul) had its roots in intertestamental literature.

\subsection{The word mach in the Hebrew Scriptures}

With regard to the Hebrew Scriptures, from the 389 occurrences of the word ruach in the Old Testament only 103 are found in pre-exilic texts, 73 in exilic (46 of these in the prophet Ezekiel) and 213 in post-exilic texts. It is notable that the word does not occur in a judicial document such as Leviticus. Spirituality and a judicial mind set seemingly do not go together. The Hebrew word ruach is also used to refer to 'wind' in general. In post-exilic texts it also refers to the 'human spirit' in two senses: as a changing emotion or experience caused by an external power (e $\mathrm{g}$ Zech 13:2; Is 29:10); as an attitude which could be described as either good or bad (e g 1 Sam 16:24-16).

Where ruach refers figuratively to God's spirit (with the literal connotation of 'wind') it suggests the experience of God's numinous presence (e g 2 Sam 22:9 smoke coming out of God's nostrils). In Isaiah 11:1 ruach indicates an eschatological 'messianic' spirit and in deutero-Isaiah 42:1 God's spirit fills all the people of God (Israel presented as the 'servant' of God) while in trito-Isaiah either Israel as entity (Is 63) or its leaders (Is 61:1) are in focus. In the prophet Ezekiel ruach indicates an altered state of consciousness (e g 11:5; 3:12, 14; 8:3; 11:1) and the renewal of humankind and creation (peculiar to Ezekiel). In Joel (2:28-32) the people filled by the ruach are not limited to leaders or elites, but includes everyone irrespective of gender, age or nationality. In Haggai (2:6) it refers to the presence of God and in Zechariah (6:6) the ruach guides God's people and their leaders.

Whatever the context or semantic usage might be the ruach of God in the Old Testament is never described as someone's possession; it is rather the principle of life or the power of renewal given to humankind. The usage of this word in the Old Testament cannot be seen as a reference to the Christians' third persona of the Triune God. In the light of its post-exilic apocalyptic connotations, the Spirit of God always refers to an external divine strength beyond humanness. This is the case for the Old and New Testaments.

\subsection{The doctrine of the Triune God}

The most ancient and best known confession of a fully developed Trinity dates back to the 2nd century CE and ultimately found expression in the 8th century Apostles' Creed 
(Apostolicum). In this, confession of faith in 'God, the Almighty' and 'Jesus, our Savior', is followed by the 'Holy Spirit', without any amplification. A Greek version of the presumably original Latin text reads: 'the Holy Spirit, the Paraclete'.

The final form of the Nicene Creed (381 CE) expands this article to: 'and in the Holy Spirit, the Lord, the giver of life, who proceeds from the Father (and from the Son - added in the ninth century, leading to the rupture between the Western and Eastern churches in the eleventh century), who with the Father and the Son together is worshipped and glorified, who has spoken through the prophets.' In the Belgic Confession (1561) (Afrikaans: die Nederlandse Geloofsbelydenis) (Articles 9 and 11) the equality of being (essence) of the three 'persons' of the Trinity is emphasized: 'We believe and confess also that the Holy Spirit eternally proceeds from the Father and the Son; not made nor created, nor begotten, but only proceeding from both; who in order is the third Person of the Trinity, of the same being, majesty, and glory with the Father and the Son; being true and eternal God as the Holy Scriptures teach us.'

So too, the Heidelberg Catechism (Lord's Day 20; Question 53) is more concerned with the 'essence' of the Holy Spirit than with its 'functions'. The second part of the Lord's Day section 20 indicates that the Holy Spirit prepares a true faith in us. The Lord's Day section 21 teaches that the Son of God, by his Spirit and his Word, preserves the church. These two articles contain elements that remind of a functional approach. The Canons of the Synod of Dordrecht (the Netherlands) (Afrikaans: die Dordtse Leerreels) (Chapter 3), confess that people do not have faith of themselves but must be regenerated by God in Christ through the Holy Spirit. In Chapter 5, this confession also (somewhat pedantically scholastic) poses the question whether or not it is possible for those who have received the life-giving Spirit to relapse, and concludes that it is not possible.

\section{THE MESSIAH AND THE CHURCH AS SPIRIT-POSSESSED}

\subsection{Luke 4:14-21}

We have seen that the proclamation of Jesus as 'Messiah' in the New Testament goes hand in hand with a description of a spiritual reality in which Jesus, empowered by the Spirit of God, conquered evil. According to Luke, Jesus puts it clearly that his 'messianic program' is the fulfillment of an Old Testament prophecy (Isaiah 61:1ff). Messiahship and messianic activity were seen as the way in which God's Spirit is at work. Because God, according to the Lukan testimony, had crowned Jesus as 'the Messiah', God's Spirit is upon him. So, if we speak about the Messiah we simultaneously speak about the Holy Spirit. The Old Testament is always kept in mind 
when New Testament texts refer to the messianic spirit. According to Luke, Jesus' messianic existence is a pneumatic existence (see $\mathrm{Lk}$ 1:35).

The following Old Testament ideas in Luke's understanding of the Holy Spirit can be distinguished: the king was the recipient and bearer of the Spirit. Accordingly, 'Messiah' was not initially an honorific, such as 'Son of Man' was an honorific for the 'end-time' Lord (cf Dan 7:13-14). Messiah signified the chosen (anointed) present Israelite king. The Israelite king was regarded as the 'son of God' (such as other ' holy men of God' in the Old Testament, $\mathrm{e} g$ prophets and the later high priest). It refers to the prophesy that the Jerusalem kingdom (the house of David) would endure for ever (cf Ps 2). In Acts 2:34-35 this kingdom is explained in terms of Psalm 110:1.

Thus Jesus is also described in Luke 1:35 and 3:22 as the 'Son of God': God gives him a throne that will endure forever (cf also 2 Sam 7). At his baptism he is also called God's Son (Lk 3:22; cf again Ps 2:7). In the Old Testament 'messiah' and 'Holy Spirit' were therefore closely connected: the king as 'son of God' was the Spiritfilled present messiah. But the kingdom of David suffered a crisis, from which arose the promises of a new kingdom from the tribe of Judah. The new king would be endowed with God's Spirit in a specific manner (cf Is 11:1ff.). The initial idea was of a future deliverer-king. In the phase after the Babylonian exile (see the prophet Zechariah) the messianic idea was theologically adapted to a new situation: the prophet expected both a priestly and a political messiah. The expectation of a future political messiah offered hope of restoration. The source of hope for the restoration of Jerusalem was not their political or military capacity as such, but God's Spirit. This idea comes closer to the New Testament. Similarly the messianic expectation of the intertestamentary period took on a political form.

Although witness of the messiah who was endowed with God's Spirit is rather diverse in the Old Testament, a uniform theme is that the Spirit enables the messiah to act. This is also the underlying theme in Luke 4:18ff: 'The Spirit of the Lord is on me, because the Spirit has anointed me to preach good news to the poor. The Spirit has sent me to proclaim freedom for the prisoners and recovery of sight for the blind, to release the oppressed, to proclaim the year of the Lord's favor' (NIV- my gender emendation).

\subsection{Acts 2: 16-2i}

In Luke's gospel we encounter the image of the Spirit-filled Messiah and in Acts that of the Spirit-filled church. In other words, in Acts the Spirit plays the leading role as the 'main character' in the church, especially with regard to the missionary activities of the apostles (and other ministers of the Word). The Holy Spirit prompts the apostles to 
witness to the risen Lord and Messiah and to his Second Coming. The climax of this proclamation is Peter's address in Acts 2:1ff. Peter quotes Joel 2:28-32 in order to proclaim the contemporary era as the era of the Spirit.

In Joel God's Spirit enables the 'sons and daughters of Israel' to proclaim God's message and, according to Acts, this is what the Spirit enables the apostles to do. Luke interprets this prophecy as the announcement of the Messiah's saving work. According to him, the church is constituted where the Holy Spirit is active. In Acts the Holy Spirit and the role of the church are closely related. In the report of the outpouring of the Spirit in Joel 2 (a document of the post-exilic era) the 'Day of the Lord' is an end-time event of consequence for the believing community. In a similar way the operation of the Holy Spirit and the end-time are closely related in the report in Acts 2. The church is an end-time (eschatological) event that terminates a previous dispensation. In the post-exilic situation the Spirit is represented as being poured out not only on the messiah (i e, ling - see Is 11) but on the whole Israel (including converts from the gentiles and other previous outcasts). This representation occurs in various places in Acts, for example in Acts 10:4.

The 'salvation history' of Luke is therefore characterized by development. In the gospel, God's Spirit empowers the Messiah and the 'time when the people of God will be saved' (the 'Sabbath year') is announced; in the Acts of the Apostles, God's Spirit empowers the apostles and the Spirit is 'poured out' on all believers (both men and women, young and old, Israel and the nations). The Spirit-filled church begins to live and proclaim the end-time, the 'Sabbath year', throughout the world.

\subsection{The Gospel of John}

Two basic matters determine John's concept of the Spirit/Paraclete/Comforter/Advocate: the Spirit is life-giving (a new dispensation with the coming of Jesus makes a new birth possible for people - cf Jn 7:37-39; 8:31-47) and testifies to the truth (God's Spirit represents believers when they are accused by the world - of Jn 16:5-15). John and Luke refer to Jesus as 'bearer' of the Spirit in the period before the resurrection. After Easter the gift of the Spirit was bestowed on the disciples (cf Jn 7:39). Before Easter Jesus already referred to the Spirit as a present reality. What John has in mind can be expressed in the word 'community'/'fellowship' (in Greek: koinonia - of $1 \mathrm{Jn}$ 1:3), specifically the mutuality of those who serve the Father 'in Spirit and in truth'. Receiving the Spirit results in communion/fellowship with the Father and the Son (see again 1 Jn 1:3). In both Acts 2 and John 20:22 it is reported that the disciples received the Spirit. Receiving the Spirit sets the missionary movement in motion. After Easter the Spirit empowers the church. Those who hear the word of the Spirit (the truth) receive life. This implies a new being and existence. 
This is similar to Paul's understanding of the Spirit. The 'new being' is parallel to Paul's concept 'new creation' (in Greek: kaine ktisis - cf 2 Cor 5:17; Gl 6:15). The Spirit of God is the Spirit of freedom (compare 2 Cor 3:17 with Jn 3:8). If people, in obedience to their Lord, open themselves to the work of the Spirit, the Spirit renews creation.

\section{THE PAULINE VIEW - ILUSTRATED BY ROMANS 8}

According to Romans 8:4ff two contrary principles orient human existence. The first is an existence according to the 'flesh' (in Greek: sarx). This is a life dominated by the power of sin, selfishness and a sense of achievement engendered by obedience to the Mosaic law (according to the Temple cult of 'Israel after the flesh'). However, according to Paul, sarx is destined toward transitoriness and death and this is common to all of creation. The other principle is the existence according to the Spirit (in Greek: pneuma). This is a life controlled by grace and love as the law of Christ. A life according to pneuma is simultaneously transitory and enduring. There are, therefore, two categories of people: those who belong to the powers of evil, whose existence is subject to the law of death, and those who live in the sphere of the Divine Spirit.

This orientation does not derive from free will: the flesh-oriented are in captivity to the power of sin and cannot escape it without God's gracious saving act. Only those who believe (and are baptized) are recreated for existence in the sphere of the Spirit and are enabled by the Spirit to direct their thoughts and deeds toward the 'things of the Spirit'.

Romans 8 is not based on the Old Testament, yet there are parallels with Ezekiel 36:25-27 and 37:5-10. In these Old Testament passages and also in Romans 8 God's saving act is the basis for the gift of the Holy Spirit. This gift enables people to focus their 'inner being' on God. Those previously under God's wrath now enter into God favor, become free before God and live in the right relationship with God. The Spirit brings about a radical change: from slavery to freedom in a radically new existence.

The phrase 'according to the (S)pirit' presents an exegetical problem. Does '(S)pirit' (in Greek: pnewma) here refer to the human spirit or to God's Spirit? Acts 8:6 demonstrates that Paul did, on occasion, use pneuma with reference to the human spirit. Mostly, however, it is used to indicate God's Spirit. The 'human spirit' means the ' $I$ ', the human self. The self is transformed into an existence controlled by the Spirit of God. Only then can on be open to the new things brought about by God.

Ezekiel's idea of a new creation is relevant here. In Ezekiel Israel's disobedience is transformed into a life of obedience, an existence controlled by God's Spirit. In Paul's thought too, there is the expectation that, for those who surrender their lives to 
the control of the Spirit, God's salvation will become visible when Christ comes in glory. This will happen within the historically experienced sphere of the church. Those set right in relationship with God through faith will experience the final judgement as people who have already been acquitted. There are, however, differences between Ezekiel and Paul. Ezekiel says that the Spirit enables humans to keep God's law. But the prophet did not foresee the misuse of the law in later times. During the first century, for example, the Pharisees used the law to enslave people to this-worldly measures. According to Paul obedience to the law leads to self-righteousness, but the Spirit sets us free from the law. Both Ezekiel and Paul had in mind the termination of a state of being unto death.

In both the Old and New Testaments, therefore, the work of the Spirit relates to what God does with people. What God does, God does through the Spirit, who is, as it were the 'power of God'. For Paul it is the same: living in Christ/in the Lord (Paul's idea of the church) is living in the Spirit. There is only one Holy Spirit. The Spirit is the bond, which unites believers with one another. This fellowship is rooted in the saving acts of Jesus. The Pauline formula of being 'in Christ/in the Lord' gives expression to the very ground of being of the community of faith, to its spiritual (pneumatic) existence. These Pauline expressions are the basis of the New Testament understanding of the church.

The origin of the church is work of Jesus of Nazareth. However, God's life-giving presence is not experienced only in the absence of the problems of life. The seemingly contradictory nature of Jesus' birth and death on a cross (born to die) reveals the manner in which God is present in the midst of, and even on the grounds of, affliction. Naturally, human beings do not experience this life-giving presence of God as a matter of course; it is the grace (in Greek: charis) of God. The gospel of Jesus Christ as good news is therefore a paradox, an apparent contradiction. After all, the power of the resurrection belief is impossible without the affliction of the cross. This grace (charis) of God accomplishes joy (in Greek: chara) amidst the afflictions of life (cf 1 Th 1:6). Joy and grace can only be received in faith and are the spiritual gift (in Greek: charisma) of the Spirit of God - who is also the Spirit of Jesus Christ (cf Rm 8:9).

The believer's life in the church is in the sphere of activity of God's Spirit. The Spirit permeates the existence of the faithful and as such they exist as 'church' (in Greek: ekklesia), as 'body of Christ' (in Greek: soma Christou - cf 1 Cor 12:27), 'one body in Christ' ( $\mathrm{Rm}$ 12:5). These terms do not merely express the unity of the church; according to 1 Corinthians 12:12-30 they also reveal that the unity of the church surpasses the will and the action of individuals. Paul describes the church as primarily 'the body of Christ'. The parts of the body are equal because they belong to 
Christ. Too much must not be made of the diversity of the parts as such. Their differences are unimportant ( 1 Cor $12 f)$. The unity of the body exists despite the differences of the parts. The unity depends on Christ. Romans 12:5 implies the same. Thus the body of Christ exists not in and because of its various members, but before they were there and irrespective of them: '(A)ll of us, whether Jews or Gentiles, whether slaves or free, have been baptized into the one body by the same Spirit, and we have all been given the one Spirit to drink' (1 Cor 12:13).

Twice Paul speaks of the 'new creation' (in Greek: kaine ktisis) with reference to the work of the Holy Spirit: Galatians 5:16-6:10 and 2 Corinthians 5:17. Ezekiel also had a 'new creation' in mind. In Galatians 6 too the dominant theme is the Spirit, and the believer's existence in the Spirit is defined by means of the term 'new creation'. The new creation is creation in the Holy Spirit. With regard to Romans 8, Paul's understanding of the Spirit is fully integrated with his view that it is only through faith that people are put in the right relationship with God. For Paul the righteousness of God is the horizon of understanding of the work of the Holy Spirit. The work of the Spirit forms the focus of God's righteousness, in other words of how God puts us in the right relationship with Godself.

\section{CHARISMATIC GIFTS - ILLUSTRATED BY 1 CORINTHIANS 12}

\subsection{The word 'charisma'}

In 1 Corinthians 12:4-6 the three words 'gift' (in Greek: charisma), 'ministry' (in Greek: diakonia) and dynamic activity' (in Greek: energema) are used. 'Gift' indicates that the source is outside oneself. 'Service' has the purpose of the gift in mind and 'effect' pertains to the 'performance' of the gift.

Charisma can only be understood as a specific manifestation (revelation - vs 7) of the work of the Spirit: it is always an act of God's grace through human beings. In other words, the human being is the 'agent' of a spiritual gift, and not its 'source'. Charisma is not a 'possession' or an 'office', but a particular manifestation of grace. It is also not a human 'reaction' to grace. Charisma is a gift, not an achievement. Service and dynamic acts are human activities. Yet charismata are not under the control of human beings. In Paul's world its performative effect pertains to an ecstatic occurrence. This points to charisma as an irrational happening that surpasses human understanding and control.

Service plays a bigger role in some charismata and ecstasy in others. However, all the charismata referred to in 1 Corinthians 12 imply a consciousness of grace, a gift received from outside the ordinary course of human life. This gift empowers people to 
experience authentic life. Therefore charismata are not to be confused with human talents and natural abilities. They are always God's deeds, manifestations of God's Spirit.

\subsection{The benefit of charismatic gifts}

In 1 Corinthians 12 we find a list of charismata (read 1 Cor 12:7-10, 28-30): a message full of wisdom, a message full of knowledge, faith, the power to heal, the power to work miracles, speaking God's message (i e 'prophecy'), distinguishing between spirits, speaking in strange tongues (glossolalia) and interpreting what is said, helping others and directing them.

One is struck by the diversity of the gifts (vs 4, 5 and 6), but this is not what it is about. Diversity is not the essence of the matter. The 'one and the same Spirit' (vs 4, 11), Lord (vs 5), God (vs 6) are the essence (note the triplication in the light of our earlier discussion on the triadic formula). The 'manifestation'/"revelation' of the Spirit is to the advantage of all (vs 7) in the church, the one body into which Israelites and Greeks, slaves and free have been baptized (vs 13). The diversity is what is visible. According to the Greek philosophy of middle-Platonism, which influenced Paul, what is visible is not what is really important. What cannot be seen, is the essence. The unity of the body of Christ is what really matters (read 1 Cor 12:14-28). The Spirit, who cannot be seen, unites the members to form the one body of Christ.

According to Paul all of this can be described by the word love (1Cor 13). God's Spirit sets us free from the chains that bound us to transitoriness, to selfishness, to ourselves (read 1 Cor 13). The Spirit sets us free for one another, free to be able to love as Christ loved us. This freedom is not an excuse to become a slave of sarx again. The Spirit makes room for love. The fruits of the Spirit, of which Paul speaks in Galatians 5-6, are the products of love. Conversely the vices referred to in Galatians are the product of living according to our 'sinful nature', of a life that testifies to our selfish attachment to self, to earth-bound 'values' of a transitory nature. But love never perishes and it is not of a transitory nature. Even charismata, faith and hope may disappear, but love endures, it never fails (1 Cor 13:8a). What matters in the church is harmony, the reconciliation of the different parts of the body. Thus Christ is revealed in the rendering of service and the effect of spiritual gifts.

\subsection{The inclusivity of the list in 1 Corinthians 12 ?}

The list in 1 Corinthians 12 is time-bound and culture-bound. They are gifts relating to specific people's 'state of altered consciousness. This consciousness will manifest dif- 
ferently in cultures influenced by modern natural science. The spiritual experiences of people living along the Mediterranean seaboard may well differ from those of modern Europeans. On the other hand, traditional religious experiences of the people from Africa bear closer similarities to those of the Mediterraneans. Therefore, the list in 1 Corinthians 12 does not apply as a complete list for all faith communities of all times and in all situations.

Paul himself is, in a certain sense, more 'charismatic' than, for example, Jesus, as can be seen from his views on of ecstasy and visions. But Paul is also. less 'charismatic' than Jesus, since fewer healings and exorcisms are associated with him.

\subsection{Charismatic gifts as 'supernatural' phenomena}

In emphasizing the diversity of charismata in 1 Corinthians 12:4-10, Paul uses the following phrases: performing service and powerful activities. Service and a wholesome effect characterize all spiritual gifts. All activities are 'charismatic' in so far as they are the deeds of God's Spirit. However, for Paul charisma indicates an occurrence brought about by divine power. It is 'divine energy' which produces a specific result for an individual within the collective context. Together they form the 'body' (in Greek: soma).

For Paul 'miracles' (in Greek: dunameis) signify occurrences in which people and things are visibly and beneficially affected in an extraordinary manner by a non-rational force. These occurrences are brought about through the mediation of Paul or other believers. Another aspect in the list of 1 Corinthians 12:8-10 is 'faith' (in Greek: pistis), relating to a 'contemplated experience', arising from the believer's general relation to God. Faith means trusting in God and relying upon God with total dependence and commitment. It is an experience that amounts to a non-rational act of gaxing upon God.

\subsection{Charismatic phenomena as 'the manifestation of the Spirit'}

Paul also describes 'charismatic' phenomena as 'the manifestation of the Spirit'. A 'revelation' (in Greek: fanerosis) by the Spirit is not a gift received by some only. Every gift is a manifestation of the Spirit (1 Cor 12:3). The most important event described as a fanerosis by Paul is of an end-time nature - making known the mystery of God's final purpose with humankind and God's creation. Christ himself is the mystery. In him, his death and life, God reveals God's way to reconciliation. 
'Revelation' is when the exalted (heavenly) Christ as the exalted Lord shows himself outside of normal human experience. Such an experience can only be articulated by means of metaphors taken from normal human experience. In other words, the 'end-time revelation' is seen as under God's control and not the product of the faculty of humankind. 'Revelation', thus, is not restricted to the act of proclaiming the Word of God.

\subsection{The nature of charismatic gifts}

\subsubsection{Ecstasy versus reason}

Paul himself also experienced other 'revelations'. It would seem that these experiences offered him insight into 'divine realities' as opposed to 'human realities.' Among these 'revelations' were ecstatic experiences and experience of the risen crucified Christ. These experiences were not strange to Paul, but it is impossible to determine how often they occurred and how ecstatic they were.

\subsubsection{Prophecy (in Greek: profeteia)}

A 'particular revelation' of a more rational nature is also possible. A specific understanding is communicated on a rational level. This is the case where 'revelation' is associated with 'prophecy'. 'Knowledge' (in Greek: gnosis), in the sense of (gnostic) 'esoteric knowledge', is the recognition of God's activities, particularly what God did in the crucified Christ. 'Wisdom' (in Greek: sofia) and 'knowledge' (gnosis) as such are not charismata; only the actual expression of 'wisdom', communicating wisdom and knowledge to others, is a charisma.

\subsubsection{Spiritual direction' (in Greek: kubernesis)}

'Spiritual direction' is a gift of God. Those who have received it are convinced that what they decide and do is according to God's will. There is, then, a clear 'charismatic' dimension to Paul's ethics: Christian action is determined by the Spirit ( $R m$ 8:4). The primary motivation was no longer obedience to a written law, but obedience to an inner obligation - i e, the 'law of the Spirit', the 'law of Christ', namely love. This means that the believer acts correctly, in other words impelled by love, not because of a prescription of the law or because of a reward in this life or in life hereafter. 


\subsubsection{Testing the spirits (in Greek: diakriseis pneumaton)}

'Testing'/'discernment' also has bearing on ethical decision-making: it implies a spontaneous awareness of God's will in concrete situations and moral dilemmas in the here and now. Characteristic of Paul's ethics is the 'charismatic' recognition of God's will, the inner conviction of God's love and giving love.

\subsubsection{Inspired utterances (in Greek: gene glosson)}

'Inspired utterances' (i e, glossolalia) indicate that Spirit and utterance go together. Of central importance was Paul's conviction that his preaching of the gospel could be described as 'charismatic'. His words and their effect had little to do with himself (cf 1 Th 1:5; 1 Cor 2:4ff). For Paul prophetic pronouncements played an important part in the edification of the church (1 Cor 14). 'Prophecy' is a word of 'revelation', it is a spontaneous utterance, and a divine revelation given to prophets in the words that they must communicate. 'Prophecy' is 'inspired speaking.' It is not a technique or a talent, but a charisma, in the sense that it is, as it were, the speaking of the 'words of the Spirit' in a specific situation. In this respect, 'prophecy' is important because it edifies, encourages and comforts the believing community and because it is a 'word of revelation' that serves as a sign for the faithful. 'Prophecy' addresses people at the level of their understanding and makes them aware that they are in God's presence. Paul was apparently of the opinion that the abuse of the gift of prophecy had to be guarded against, the criterion being the edification of the believing community.

'Teaching' is also a 'charismatic' deed ( $R \mathrm{~m} \mathrm{12:7):} \mathrm{it} \mathrm{deals} \mathrm{with} \mathrm{specific} \mathrm{subject}$ matter and seeks to draw new insights from what is believed to be 'an old word of God'.

'Singing' can also be regarded as spontaneous 'charismatic singing', 'singing with the Spirit' (1 Cor 14:15).

Similarly, there is a large measure of spontaneity involved in prayer. Like Jesus, Paul also knew the Abba prayers. By means of these prayers believers affirm that they are children of God. Abba prayers indicate 'sonship'/"being a child', in other words that believers derive their origin from God. As children in that culture were obedient and loyal to their father, so God's children are obedient and loyal and trust in God. Prayer is also 'inspired utterance'.

With regard to glossolalia (the use of unusual languages or sounds), there was clearly a difference between the Corinthian glossolalia and glossolalia acceptable to Paul. In Corinth glossolalia were a form of ecstatic utterances, sounds, cries and words in a state of spiritual ecstasy within the context of the Graeco-Roman mystery religions. This, Paul says, has no place in Christian worship (1 Cor 12:2) and must be 
discouraged (1 Cor 14:5-12, 19). Yet Paul allowed it a role in the Corinthian community. He mentions it last in the list of gifts and regards it as childish (1 Cor 14:20); yet he calls it a charisma. He sees it as a kind of 'heavenly language', as a kind of prayer (1 Cor 14:2): people who experience glossolalia have an experience of affective communication with God; the prayer that they cannot articulate, the Spirit articulates on their behalf. Nevertheless, Paul clearly opposes abuse of this gift. He regards it as a service to others, a manifestation of the Spirit for the communal good (1 Cor 12:7). The one who speaks in tongues is a member of the congregation. Although it is permitted, it is not strongly recommended. It is advantageous if it is accompanied by interpretation (in Greek: hermeneia glosson - of 1 Cor 12:10) for the benefit of the congregation (1 Cor 14:15).

It would seem that Paul was trying to control existing practices in Corinth that he could not forbid. Therefore the interpretation of tongues and the congregation's control over the exercise of this gift would serve as a safeguard against abuse. In other words, even the limited space Paul allows it is subject to control for the sake of a sound balance.

\subsubsection{The 'ability to help' (in Greek: antilempsis)}

With the expression 'ability to help' Paul describes the manifestation of grace as service. This may relate to specific charismata, for example 'collection' and 'hospitality'. For Paul 'helping' represents the totality of service. He regards giving to the poor as charisma in so far as it reflects God's undeserved goodness in Christ. The 'provision of help' (antilempsis) and the 'word of direction' (kubernesis) are regarded as charismata.

\subsubsection{Healing (in Greek: iama) and wholeness}

The gift of healing must be seen in terms of the distinction between 'faith healings' and 'plant (biochemical) healings.' Within Graeco-Roman culture the former were often associated with magic. In the New Testament world, healings related primarily to religious 're-socialization'.

\section{SPIRITUALITY - A THREAT?}

Charismata also can pose a threat to the church. What happened in practice? On the strength of 1 Corinthians we get the impression that charismatic experiences resulted in impatience, jealousy, arrogance and selfishness. A lack of love and faith displace unity. In 2 Corinthians a problem seemingly arose because of the charismata of false 
prophets who apparently had inspired ecstatic experiences but displayed a kind of superiority and arrogance towards others. With regard to the church in Rome, Paul says that he is aware of great dissension. According to the traditional interpretation of the Thessalonian letters, 'charismatic enthusiasm' also got out of control. Here too charismata threatened the unity of the church.

Unity by virtue of a diversity of gifts is not a natural human endowment. Therefore anything that threatens the community, that threatens its unity of faith and the unity of the body, is ipso facto not a charisma and does not derive from the Spirit of God. Any charisma, however impressive as it may be, which is experienced without love, impairs the growth of the church. Since each believing community was a 'charismatic community', 'criteria for control' were necessary. Charismata cannot exist outside of the community of faith. And without charismata a church is devoid of life and grace. The charismata are intended to build up the believing community. There is no 'hierarchy of office'. For Paul the community of faith is dependent on the Holy Spirit. Yet there are dangers attached to charismata. Therefore enthusiasm and 'control' are necessary. The following measures of control can be found in Paul's correspondences: inherent control (that is an 'expression of wisdom' - in Greek: logos sofias; cf 1 Cor 12:8), 'apostolic' (in Greek: apostoloi), 'prophetic' (in Greek: profetai) and 'teaching' (in Greek: didaskaloi) authority (cf 1 Cor 12:28, 29). In the Deutero-Pauline epistles 'shepherds and teachers' (cf Eph 4:11), 'proclaimers of the gospel' (in Greek: euangelistai - Eph 4:11) and the community of faith as a whole can be seen as 'criteria for control'.

The fact that charismata can pose a threat to the unity of the church, should under no circumstances cause spirituality to be undervalued in the church. If this should happen, preserving the authority of office-bearers could easily become the raison d'etre of the church. Charismata are not offices and offices are not charismata. In the earliest church offices developed within patriarchal structures where heads of families held positions. Charismata are not connected with a position. How office-bearers interacted with subordinates indicated whether they were bestowed with charismata or not. According to Paul this can be seen in love and in service.

\section{RECOMMENDED PUBLICATIONS}

Bauckham, R J 1980. The role of the Spirit in the Apocalypse. EvQ 52, 452-466.

Bergmeier, R 1995. Gottesherrschaft, Taufe und Geist: Zur Tauftradition in Joh 3. ZNW 86/1 \& 2, 53-73.

Betz, O 1963. Der Paraklet: Fursprecher im häretischen Spatjudentum, im JohannesEvangelium und in neu gefundenen gnosttischen Schriften. Leiden: Brill. (Arbeiten zur Geschichte des Spätjudentums und Urchristentums 2.) 
Breck, J 1991. Spirit of truth: The Holy Spirit in Johannine tradition. Crestwood, NY: St Vladimir's Seminary Press.

Bruce; F F 1973. Holy Spirit in the Acts of the Apostles. Interpretation 27, 166-183. Busse, U 1993. Aspekte biblische Geistverständnisses. Biblische Notizen 66, 40-58.

Casurella, A 1983. The Johannine Paraclete in the church fathers: A study in the history of exegesis. Tübingen: Mohr. (Beiträge zur Geschichte der biblischen Exegese 25.)

Clements, R E 1978. The presence of God, in Old Testament theology: A fresh approach, 66-72. London: Marshall, Morgan \& Scott. (Marshalls Theological Library.)

Dunn, J D G [1975] 1997. Jesus and the Spirit: A study of the religious and charismatic experience of Jesus and the first Christians as reflected in the New Testament. Originally published by SCM Press. Grand Rapids, MI: Eerdmans.

Fee, G D 1994. God's empowering presence: The Holy Spirit in the letters of Paul. Peabody, MA: Hendrickson.

1995. Paul, the Spirit, and the people of God. Peabody, MA: Hendrickson.

Goldingay, J 1988. 'Holy Ones on High' in Daniel 7:18. JBL 107/3, 495-597.

Gunkel, H 1979. The influence of the Holy Spirit: The popular view of the apostolic age and the teaching of the apostle Paul - A biblical-theological study, tr by R A Harrisville \& P A Quanbeck. Philadelphia, PA: Fortress.

Haufe, G 1994. Das Geistmotiv in der paulinischen Ethik. ZNW 85/3 \& 4, 183-191.

Hildebrandt, W 1995. An Old Testament theology of the Spirit of God. Peabody, MA: Hendrickson.

Hoenderdaal, G J 1968. Geloven in de Heilige Geest. Wageningen: Veenman en Zonen. (Cahiers bij het Nederlands Theologisch Tijdschrift 2.)

Horn, F W 1992. Das Angeld des Geistes: Studien zur paulinischen Pneumatologie. Göttingen: Vandenhoeck \& Ruprecht.

Hübner, H 1990. Der Heilige Geist in der Heiligen Schrift. Kerygma und Dogma 36, 181-208.

Isaacs, M E 1976. The concept of spirit: A study of pneuma in Hellenistic Judaism and its bearing on the New Testament. London: Heythrop College. (Heythrop Monographs 1.)

Jacob, E [1955] 1958. The instruments of God's action: The Spirit, in The theology of the Old Testament, 121-127, tr by A W Heathcote \& P J Allcock. London: Hodder and Stoughton.

Jeske, R L 1985. Spirit and community in the Johannine Apocalypse. NTS 31, 452466.

Kerr, A J 1988. 'Arrabon'. Journal of Theological Studies 39, 92-97. 
Kirk, J A 1969. The meaning of wisdom in James: Examination of a hypothesis. NTS 16/1, 24-38.

Knoch, O 1975. Der Geist Gottes und der neue Mensch: Der Heilige Geist als Grundkraft und Norm des christlichen Lebens in Kirche und Welt nach dem Zeugnis des Apostels Paulus. Stuttgart: Verlag Katholisches Bibelwerk. (Geist und Leben.)

Knibb, M A 1985. Martyrdom and Ascension of Isaiah, in Charlesworth, J H (ed), The, Old Testament pseudepigrapha, Vol 2: Expansions of the 'Old Testament' and legends, Wisdom and philosophical literature, prayers, psalms, and Odes, fragments of lost Judeo-Hellenistic works, 143-176. New York: Doubleday.

Lull, D J 1980. The Spirit in Galatia: Paul's interpretation of pneuma as divine power. Chico, CA: Scholars Press. (SBL Dissertation Series 49.)

Malatesta, E 1973. Spirit/Paraclete in the Fourth Góspel. Biblica 54/4, 539-550.

Mansfield. M R 1987. 'Spirit and gospel' in Mark. Peabody, MA: Hendrickson.

Menzies, R P 1994. Empowered for witness: The Spirit in Luke-Acts. Sheffield Academic Press. (Journal of Pentecostal Theology Supplement Series 6.)

Montague, G T 1994. Holy Spirit: Growth of a Biblical tradition. Peabody, MA: Hendrickson.

Müller, U B 1974. Die Parakletenvorstellung im Johannesevangelium. ZThK 71/1, 31-77.

Przybylski, B 1984. The Spirit: Paul's joumey to Jesus and beyond, in Richardson, P \& Hurd, J C, From Jesus to Paul: Studies in honour of Francis Wright Beare, $157-$ 167. Waterloo, Ontario: Wilfrid Laurier University Press.

Shepherd, W H 1994. The narrative function of the Holy Spirit as a character in LukeActs. Atlanta, GA: Scholars Press. (SBL Dissertation Series 147.)

Tatum, W B 1967. Epoch of Israel: Luke 1-2 and the theological plan of Luke-Acts. NTS 13,184-195.

Rea, J [1990] 1992. The Holy Spirit in the Bible: A commentary on the major passages. Originally published by Creation House. London: Mashall Pickering.

Schafer, P 1972. Die Vosrtellung vom heiligen Geist in der rabbinischen Literatur. München: Kosel. (Studien zum Alten und Neuen Testament 28.)

Shelton, J B 1991. Mighty in word and deed: The role of the Holy Spirit in Luke-Acts. Peabody, MA: Hendrickson.

Swetnam, J 1993. Bestowal of the Spirit in the Fourth Gospel. Biblica 74/4, 556-576.

Turner, M 1991. The Spirit and the power of Jesus' miracles in the Lucan conception. Novum Testamentum 33, 124-152.

Vledder, E J \& Van Aarde, A G 1991. A holistic view on the Holy Spirit as agent of ethical responsibility: Exciting in Romans 8, but alarming in 1 Corinthians 12. HTS 47, 503-525. 
Wilkens, W 1967. Wassertaufe und Geistempfang bei Lukas. Theologische Zeitschrift 23, 26-47.

Williams, S K 1987. Justification and the Spirit in Galatians. Journal for the Study of the New Testament 29/91-100. 